\title{
A New Strategy for Determining Optimum pH of Isozymes
}

\author{
Kil-Joong Yoon \\ Division of Applied Sciences, Cheongiu Lniversity, Cheongin 360-764, Korea \\ Received February 16, 2004
}

\begin{abstract}
A hydrogenperoxide sensor containing peroxidase extracted from horseradish was constructed and $\mathrm{pH}$ effect on its sensing ability was investigated. Current profiles of the biosensor with $\mathrm{pH}$ and the electrophoretic analysis showed that horseradish peroxidase consists of two isozymes. Assuming that it is a hypothetical twoisozyme mixture. the current profiles were deconvoluted into two Gaussians. Application of the new MichaelisMenten equation connoting $\mathrm{pH}$ concept to this system enabled to find all the related dissociation constants of the isozyme-substrates and the isozyme-proton complexes and to determine $\mathrm{pHs}$ for the maximal isozyme activities.
\end{abstract}

Key Words : Biosensor. Enzyme electrode. Hydrogen peroxide. Peroxidase. Isozyme

\section{Introduction}

The most striking characteristics of enzymes are their immense catalytic power and high specificity in the biological system. The structure and the function of an enzyme are determined by the sequences of amino acids of which the protein is made. The active site of an enzyme. which takes up a relatively small part of the total volume of the enzyme. is a three-dimensional entity and a crevice formed by residues that come from different parts of the linear amino acid sequences. So a change in $\mathrm{pH}$ can have a number of distinct effects on enzy'mes. e.g. inactivation of the enzyme. a change in the ionization state of the enzyme or a change in the equilibrium position outside a certain $\mathrm{pH}$ range. This means that enzyme-catalyzed reactions are dependent on proton concentration in the biological system. In 1913. Michaelis and Menten proposed a simple model to account for the kinetic properties of many enzymes. But they had no cognizance of $\mathrm{pH}$ effect that exerts a far-reaching influence on the reaction rates. Even though reaction rate is not dependent on $\mathrm{pH}$ only. their having no consideration of $\mathrm{pH}$ effect is a crucial weak point in their establishment. But application of the new Michaelis-Menten equation. which considered $\mathrm{pH}$ effect. to our system enables to find all the dissociation constants of the related chemical species in our biological sy stem. ${ }^{1-4}$

Quantitative determination of hydrogen peroxide is very important in many fields of industry. biochenistry and environmental chenistry. ${ }^{5,6}$ Here if the reaction is especially involved in redox process, electrochemical methods are still more efficient tools in the quantitative analy sis of biological material. Lots of electrochenical approaches to sense hydrogen peroxide have ever been carried out. ${ }^{7 a-t}$ Consequently. a lot of biosensors which are modified with the biocatalytic materials such as animal or plant tissue ${ }^{\text {sa.f }}$ have been constructed and their electrochemical behaviors. for example. response time. potential and $\mathrm{pH}$ dependence, long term stability. optinization of mediator concentration. effect of the tissue composition and so forth. have been investigated.
We had ever defined a $\mathrm{pH}$-dependent current function. $\mathrm{G}\left(\mathrm{H}^{+}\right)$. to determine the optimum $\mathrm{pH}$ of enzyme electrochemically when a biosensor has only one catalytic component and already reported the results. But $\mathrm{pH}$-dependent current profile of the peroxide sensor containing cabbage tissue $y$ showed that its intensity does not depend on only one enzyme but on two active isozymes in our previous study. 1 .j.-15 Because we have not ever had any appropriate method to the analysis of such a system as has more than one catalytic enzyme two new assumptions. which are very central to the present work, were supposed to treat with our system. These are as follows: 1) The reduction function of cabbage tissue based transducer catalyzed by peroxidase is Gaussian distribution with $\mathrm{pH}$. 2) $\mathrm{pH}$-dependent current profile of cabbage root-tissue based amperometric electrode is the sum of the two Gaussians. which show two current peaks at two different $\mathrm{pHs}$. Then, we developed a carbon paste electrode with the commercially available peroxidase extracted from horseradish because horseradish and cabbage belong to the same taxonomical family, cruciferae. ${ }^{16}$ It showed the same phenomena as cabbage tissue based sensor did. Based on the assumptions mentioned above. $\mathrm{pH}$-dependent current profiles of the enzyme electrode with horseradish peroxidase at various monitoring concentrations of substrate were resolved into two Gaussians. And application of the deconvoluted data to the new Michaelis-Menten equation enabled to determine optimum $\mathrm{pH}$ of each isozyme activity. This article is related to the approach for determining optimum $\mathrm{pHs}$ of isozymes in the system which has more than one enzyme.

\section{Experimental Section}

Apparatus. The electrodes were connected to a BAS Model EPSILON cyclic voltammograph (Bioanalytical System. Inc.. U. S. A.) for $\mathrm{CV}$ diagram. An $\mathrm{Ag} / \mathrm{AgCl}$ reference (BAS MF2052) and a Pt counter electrode (BAS MW1032) were used. And EG\&G Model 362 (Princeton Applied Research, U. S. A.) scanning potentiostat was used for other amperometric measurements. The output was recorded on a KIPP \& 
7.ONEN X-t recorder (BDIII. Holland). The $\mathrm{pHs}$ of the electrolytic solutions were checked with a Digital $\mathrm{pH} / \mathrm{mV}$ / Temp meter (Suntex SP-701, Taiwan). The electrophoresis of enzyme was run on a Dual Gel Caster (Mighty Small II kit. SГ: 250. Hoefer Scientific Inc. U. S. A.).

Chemicals. Graphite powder $(: \leq 0.1 \mathrm{~mm})$ and mineral oil were purchased from Fluka and Sigma, respectively. Hydrogen peroxide (Junsei, F., 35\%), peroxidase (Sigma, from horseradish, abbr. HRP, Г.,. 1.11.1.7) and guaiacol (Sigma) were used as received. Flectrolyte was $\mathrm{NaCl}$ (Shinyo Pure Chem. $\geq 99.5 \%$ ). pH constancy of electrolytic solution $(0.1 \mathrm{M} \mathrm{NaCl})$ was achieved by adequate adding a dilute $\mathrm{HCl}$ (Oriental Chem, $\mathrm{Co}$.) and a dilute $\mathrm{NaOH}$ (Shinyo Pure Chem.) solution.

Electrode and procedures. The electrode material used in this work was prepared as follows. ${ }^{10} 0.91 \mathrm{~g}$ of graphite powder and $10 \mathrm{ml}$. of chloroform (containing $0.09 \mathrm{~g}$ ferrocene) were mixed and then dried throughly. $100 \mathrm{mg}$ of the ferrocene immobilized graphite powder was added to $100 \mu \mathrm{l}$. of $1.0 \% \mathrm{HRP}$ solution prepared in advance and air dried subsequently. Carbon paste was made by mixing graphite powder with mineral oil at a 55:45 ratio (wt/wt). The final carbon paste had the following composition: $49.6 \%$ graphite powder, $4.9 \%$ ferrocene, $45 \%$ mineral oil, $0.5 \%$ HRP by weight. The working electrode was prepared by packing this carbon paste into a $6 \mathrm{~mm}$ i.d. polyethylene tube which is provided with the olmic contact. ${ }^{16}$ The signal was measuerd as follows. The enzyme electrode was placed in $10 \mathrm{ml}$, of $0.1 \mathrm{M} \mathrm{NaCl}$ solution under constant stirring and at an applied potential of $-275 \mathrm{mV} v \mathrm{~s}$. Ag/AgCl. And the difference between signals without and with adding substrate solution was considered to be current due to the reduction of hydrogen peroxide catalyzed by HRP on a strip chart recorder. In addition, electrophoretic expansion of peroxidase was performed in 10\% native polyacrylamide gel and visualized in the $50 \mathrm{mM}$ phosphate buffer $(\mathrm{pH} 7.4)$ containing $15 \mathrm{mM}$ guaiacol and $5 \mathrm{mM}$ hydrogen peroxide. All data were computed with KaleidaGraph 3.0 and Origin 7.0 .

\section{Results and Discussion}

Figure 1 compares two cyclic voltammograms of the enzyme electrode modified with $\mathrm{HRP}$ in $0.1 \mathrm{M} \mathrm{NaCl}$ solution (pH 6.14) without (A) and with (B) $0.02 \mathrm{M} \mathrm{H}_{2} \mathrm{O}_{2}$. Even though the shape of the voltammogram obtained after adding substrate is very similar to that of the $\mathrm{CV}$ obtained before adding substrate, the former reveals higher reduction current than the latter as soon as substrate is added.

This indicates that peroxidase exerts immense catalytic power. The difference in the current between $\mathrm{A}$ and $\mathrm{B}$, which is considered to be signal in rigure 1, showed an ohmic behaviour $\{y=-3.06-0.0377 x, R=0.993, y$ : current $(n A), x$ : potential $(\mathrm{mV})$; with the applied potential in the working potential range. Based on the above results, the operating potential of $-275 \mathrm{mV}$ was chosen in order to make a compromise between a big signal and a low noise. Figure 2

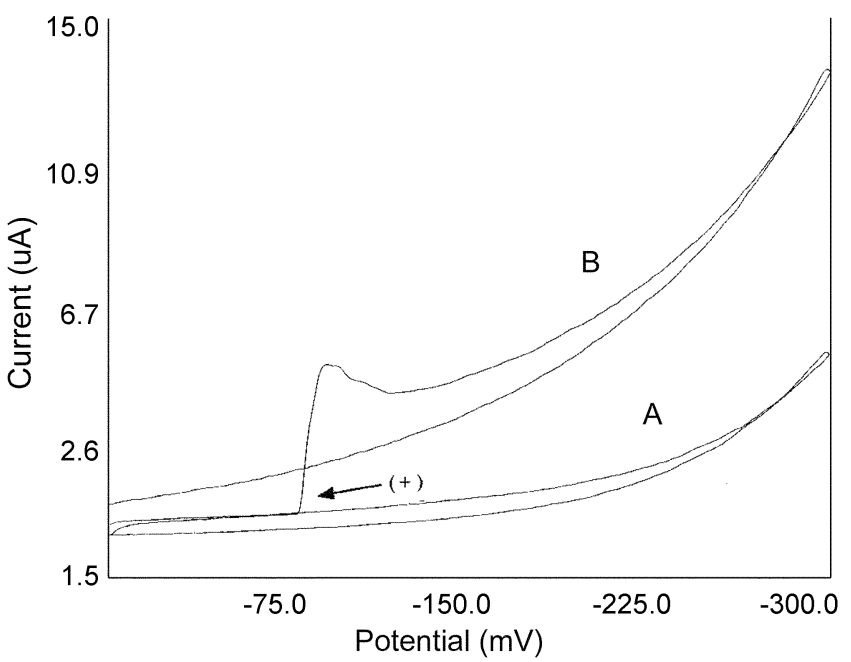

Figure 1. Cyclic voltammograms for HRP moditicd enzyme

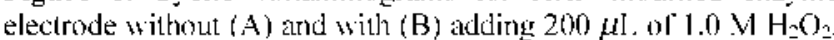
in $0.1 \mathrm{M} \mathrm{VaCl} \mathrm{with} \mathrm{a} \mathrm{potential} \mathrm{scan} \mathrm{rate} \mathrm{of} 10 \mathrm{mV} / \mathrm{s}$. The (1) indiwates the addition of $\mathrm{I}_{2} \mathrm{O}_{2}$

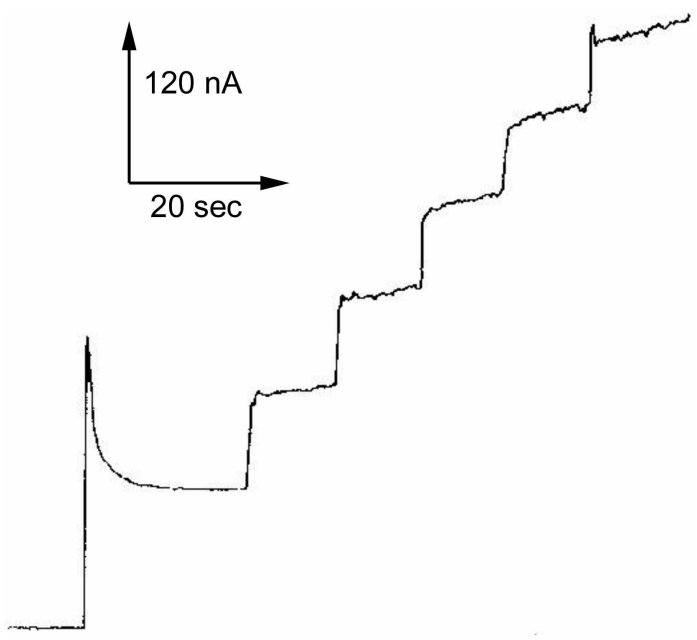

Figure 2. Typical ampurogram at pll 6.14 and at $-275 \mathrm{mV}$ for suecessive increments of $50 \mu \mathrm{L}$ of $1.0 \mathrm{M} \mathrm{H}_{2} \mathrm{O}_{2}$.

is a typical strip chart recording obtained with the HRP enzyme electrode upon successive additions of standard hydrogen peroxide to working solution. It shows that the response is linear up to the maximum working concentration of hydrogen peroxide. The linearity of signal current with substrate concentration is $y=-0.05+0.0296 x\{R=.999, y$ : current (nA), $\mathrm{x}$ : added vol. $(\mu \mathrm{L})$ of $0.1 \mathrm{M} \mathrm{H}_{2} \mathrm{O}_{2}$ \} in the range of our working concentration. Table 1 gives the $\mathrm{pH}$ dependence of the reduction currents catalyzed by HRP at a variety of substrate concentrations. Plots of currents against $\mathrm{pH}$ will therefore be of the form shown in Figure 3. And they show two clear peaks at two different $\mathrm{pH}$ values. The obserbation of these two peaks is a good evidence that two principal species are present. Figure 4 shows the dark bands of the stained protein separated at three different concentrations of peroxidase. The solutions used in electrophoresis contain peroxidase of 0.5 (lane 1), 1.0 (lane 2) and $2.0 \mu \mathrm{g} /$ 
Table 1. Effect of $\mathrm{pH}$ on the biocataly tic current

\begin{tabular}{|c|c|c|c|c|c|c|c|c|c|c|c|c|}
\hline \multirow{2}{*}{ [S]. mM } & \multicolumn{11}{|c|}{ pli } & \\
\hline & 2.33 & 3.47 & 4.66 & 6.14 & 6.70 & 7.93 & 8.94 & 9.78 & 10.86 & 11.81 & 12.42 & \\
\hline 8.4 & 60 & 177 & 231 & 222 & 174 & 99 & 126 & 129 & 90 & 60 & 8 & $\mathrm{nA}$ \\
\hline 9.9 & 70 & 201 & 264 & 252 & 192 & 120 & 144 & 144 & 102 & 75 & 9 & \\
\hline 12.0 & 82 & 225 & 303 & 291 & 216 & 144 & 168 & 162 & 117 & 93 & 11 & \\
\hline 15.0 & 94 & 264 & 348 & 333 & 252 & 180 & 198 & 192 & 135 & 117 & 15 & \\
\hline
\end{tabular}

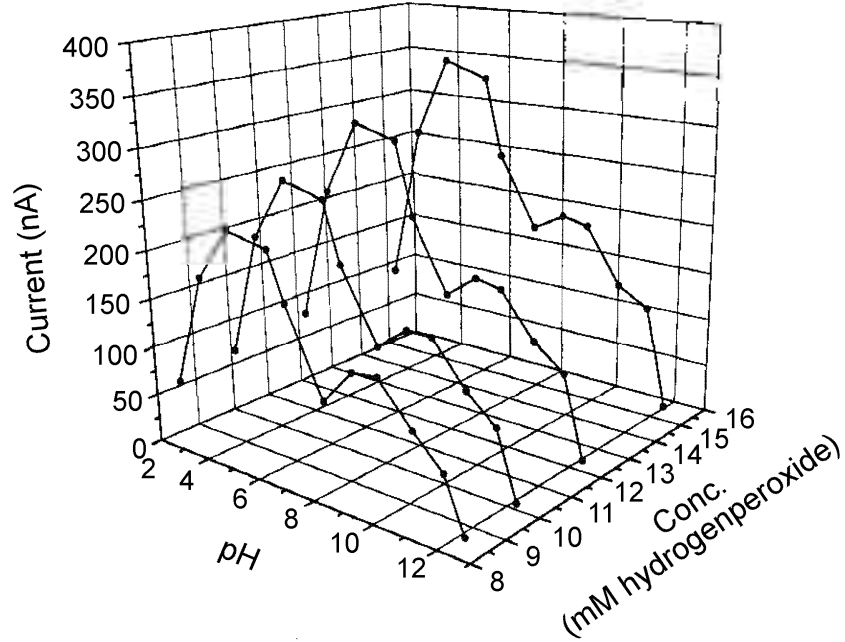

Figure 3. Dependence of the biocatalytic current on $\mathrm{pH}$ at a varicty of substrate concentrations. Other conditions are the same as in lïgure 2 .

ml. (lane 3). Two stained proteins (band 1 and band 2) are observable in lane land lane 2, respectively. And four bands are stained at the high concentration of peroxidase (lane 3), But lane 3 shows that the intensities of the two new bands (band 3 and band 4 ) which have the higher electrophoretic mobility are much weaker than those of band 1 and band 2 . This makes it possible to regard band 1 and band 2 as major bands. Two experimental results above suggest probably that two isozymes are present in the modified biosensor. Those made us assume that the current profiles in Figure 3 are the sums of two Gausians. Our assumption being quite within the bounds of possibility, a good deal of effort has been directed toward resolving them. So every $\mathrm{pH}$ dependent profile of current in lable 1 has been deconvoluted into two Gausian products and the results obtained are presented in lable 2 . Enzymes which are active in the region of the low

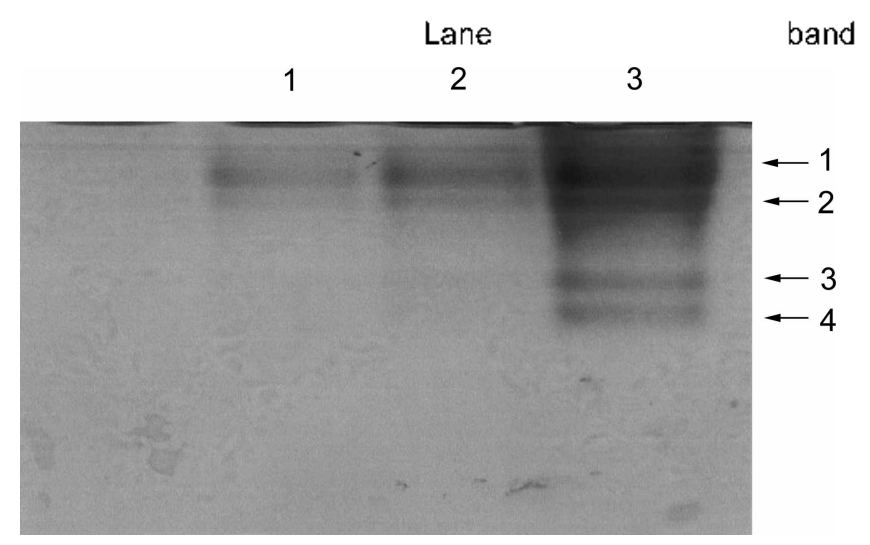

Figure 4. Native polyacrylamide gel electrophoresis of the peroxidase extracted from horseradish.

and high $\mathrm{pH}$ are referred to as isozyme $\mathrm{A}$ and $\mathrm{B}$ in this paper, respectively. The relationships ${ }^{2}$ of $\left[\mathrm{H}^{+}\right], \mathrm{K}_{\mathrm{m}}$ and $\mathrm{V}_{\text {max }}$ derived from the new Michaelis-Menten theory connoting $\mathrm{pH}$ concept can be written ats follows.

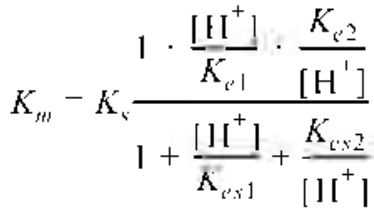

$$
\begin{aligned}
& V-\frac{V_{\max }}{1+\frac{\left|\mathrm{II}^{-}\right|}{K_{c s 1}}, \frac{K_{a 2}}{\left[\mathrm{H}^{-}\right]}}
\end{aligned}
$$

From equation (1) and (2), we can therefore write

$$
\frac{V}{K_{m}}-\frac{V_{\max }}{\bar{K}_{s}} \frac{1}{1+\frac{\left[\mathrm{H}^{\prime}\right]}{K_{c^{\prime} 1}}+\frac{K_{r 2}}{\left.[]^{+}\right]}}
$$

\begin{tabular}{|c|c|c|c|c|c|c|c|c|c|c|c|c|c|}
\hline \multirow{3}{*}{$|\mathrm{s}| . \mathrm{mM}$} & \multicolumn{12}{|c|}{ pll } & \\
\hline & \multicolumn{7}{|c|}{ Isoryme $A$} & \multicolumn{5}{|c|}{ Isoyyme I3 } & \\
\hline & 2.33 & 3.47 & 4.66 & 6.14 & 6.70 & 7.93 & 8.94 & 8.94 & 9.78 & 10.86 & 11.81 & 12.42 & \\
\hline 8.4 & 70 & 161 & 240 & 209 & 167 & 68 & 22 & 98 & 121 & 95 & 45 & 6 & $n A$ \\
\hline 9.9 & 88 & 186 & 279 & 236 & 183 & 76 & 25 & 117 & 139 & 109 & 55 & 8 & \\
\hline 12.0 & 100 & 213 & 319 & 270 & 208 & 83 & 28 & 125 & 157 & 125 & 59 & 9 & \\
\hline 15.0 & 104 & 248 & 362 & 305 & 237 & 94 & 32 & 153 & 184 & 147 & 73 & 10 & \\
\hline
\end{tabular}

Table 2. Computer deconvolution of the pH-dependent current profiles 
Table 3. Log $I_{\text {nidx }}$ and $\log \left(f_{\text {nus }} / K_{\text {m1 }}\right)$ determined by the Lineweaver-Burk plot

\begin{tabular}{|c|c|c|c|c|c|c|c|c|c|c|c|c|}
\hline \multicolumn{13}{|c|}{$\mathrm{pli}$} \\
\hline & \multicolumn{7}{|c|}{ Isozyme $A$} & \multicolumn{5}{|c|}{ Isozyme B } \\
\hline & 2.33 & 3.47 & 4.66 & 6.14 & 6.70 & 7.93 & 8.94 & 8.94 & 9.78 & 10.86 & 11.81 & 12.42 \\
\hline $\log \gamma_{\text {tax }}^{-}$ & 2.504 & 2.902 & 3.023 & 2.878 & 2.707 & 2.253 & 1.877 & 2.656 & 2.725 & 2.680 & 2.447 & 1.924 \\
\hline $\log \frac{V_{\max }}{K_{h t}}$ & 3.050 & 3.384 & 3.574 & 3.539 & 3.467 & 3.118 & 2.572 & 3.180 & 3.270 & 3.151 & 2.810 & 1.910 \\
\hline
\end{tabular}

Table 3 lists the logarithms of $V_{\text {mix }}$ and $V_{\text {mas }} K_{\text {tr }}$ that L ineweaver-Burk plots give at various $\mathrm{pHs}$ for two isozyme $A$ and $B$.

Using the above equations and Table 3, we calculate all the

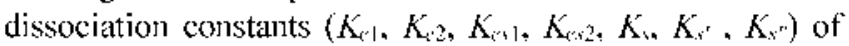
chemical species which are present in our system,

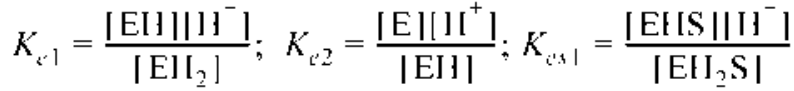

$$
\begin{aligned}
& K_{* \vee 2}-\frac{[\mathrm{ES}][\mathrm{H}]}{[\mathrm{EHS}]} ; K_{x^{\prime \prime}}-\frac{\left.\mid \mathrm{EH}_{2} \| \mathrm{IS}\right]}{\left[\mathrm{EH}_{2} \mathrm{~S}\right]} ; K_{*}-\frac{[\mathrm{EH}][\mathrm{S}]}{[\mathrm{EHS}]} \\
& K_{s^{\prime}}=\frac{[\mathrm{E} \| \mathrm{S}]}{\mid \mathrm{ES}]}
\end{aligned}
$$

This can be done as follows.

1) When $K_{(: s)}>>\left[\mathrm{H}^{+}\right]>>K_{(\mathrm{x} 2}$, a commom logarithm of the approximated equation (2) is

$$
\log V-\log V_{\operatorname{tax}}
$$

A plot of $\log V$ against a fluent, $\mathrm{pH}$ yields a straight line with a slope of 0 and this straight line cuts a vertical shaft at $\log V_{\max }$

2) When $\left[\mathrm{H}^{+}\right]>K_{2: 1}$, its common logarithm is given by the expression,

$$
\log V-\log V_{\max }+\log K_{t w 1}+\mathrm{pH}
$$

Thus, a curve of $\log V$ against $\mathrm{pH}$ is here a straight line with a one-unit slope and intersects the axis of ordinates at $\log V_{\operatorname{ma}}+\log K_{\text {a } 1 .}$ In other words the $\log V$ increases by 1 for every $\mathrm{pH}$ increase of $\mathrm{l}$ in the region.

3) When $\left.K_{22} \gg{ }^{-}\right]$, similar considerations apply also to the region, then equation (2) follows

$$
\log V-\log V_{\text {mix }}-\log K_{e x: 2}-\mathrm{pH}
$$

A plot of $\log V$ against $\mathrm{pH}$ will be a straight line with slope of -1 and intercept of $\log V_{\max }-\log K_{1 \cdot 2}$ on the vertical axis. In short, equation (4), (5) and (6) are the calculated straight lines tangent to the fitted quadratic curves of the plot, $\log V_{\max }$ vs. $\mathrm{pH}$, which intersect at a $\mathrm{pH}$ value equal to the pK. For isozyme A and B, it is easily shown that equation (4) and (5), and (4) and (6) intersect at a pH value equal to $\mathrm{pK}_{\mathrm{i}}$ and $\mathrm{pK}_{2: 2}$, respectively, at the top of rigure 5.

Also it is possible to use equation ( 3 ) in order to determine $K_{i^{\prime} 1}$ and $K_{c^{2}}$ in a fashion that is similar to the procedure mentioned previously.

4) When $K_{(1)} \gg\left[\mathrm{H}^{-}\right] \gg K_{12}$, a common logarithm of the
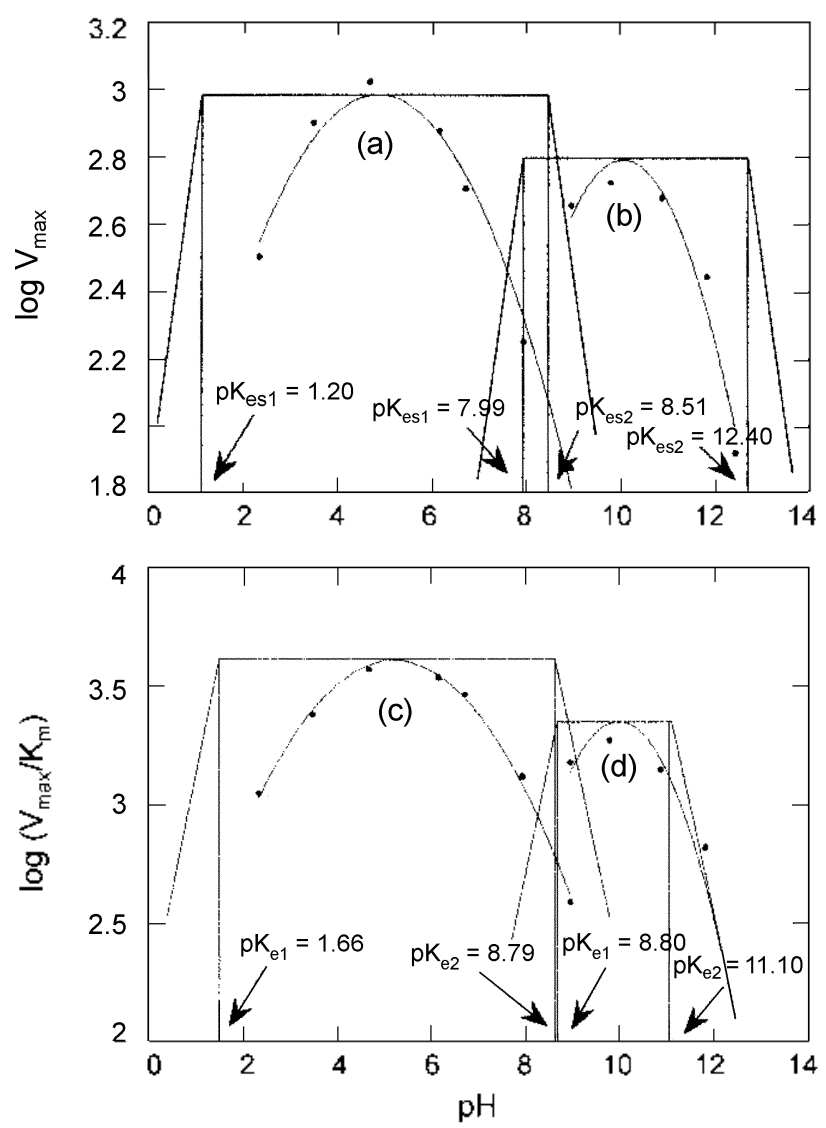

Figure 5. Lffect of pll on $\log J_{\text {max }}$ and $\log \left(V_{\text {max }} / K_{m}\right)$ of enzymecatalyzed reactions. Quadratic equations. (a) $y=-0.0687 \mathrm{x}^{2}+$ $0.665 x-1.38$ : (b) $y-0.127 x^{2}-2.53 x-1.38$; (c) y $-0.706 x^{2}+$ $0.734 x \cdot 1.71:$ (d) $y=-0.211 x^{2} \cdot 4.20 x-17.6$. here, $x$ is the axis value (pl l) of abscissa and $y$, that of ordinates.

equation (3), which was approximated, is

$$
\log \frac{V}{K_{n t}}=\log \frac{V_{\text {max }}}{K_{x}}
$$

The curve of $\log \left(V / K_{m}\right)$ against $\mathrm{pH}$ is a straight line with a slope of 0 and this straight line cuts a vertical shaft at $\log \left(V_{\max } / K_{3}\right)$. Here, the value of $K$. may readily be obtained by putting $\log \left(V_{\operatorname{ma}} / K\right.$, equal to the intercept.

5) When $\left[\mathrm{H}^{-}\right] \gg K^{\prime}$, a common logarithm of the equation (3) is given by the expression,

$$
\log \left(V / K_{m}\right)=\log \left(V_{\max } / K_{n}\right)+\log K_{K^{\prime}}+\mathrm{pH}
$$


Table 4. Gathering of thermodynamic parameters of isozymes

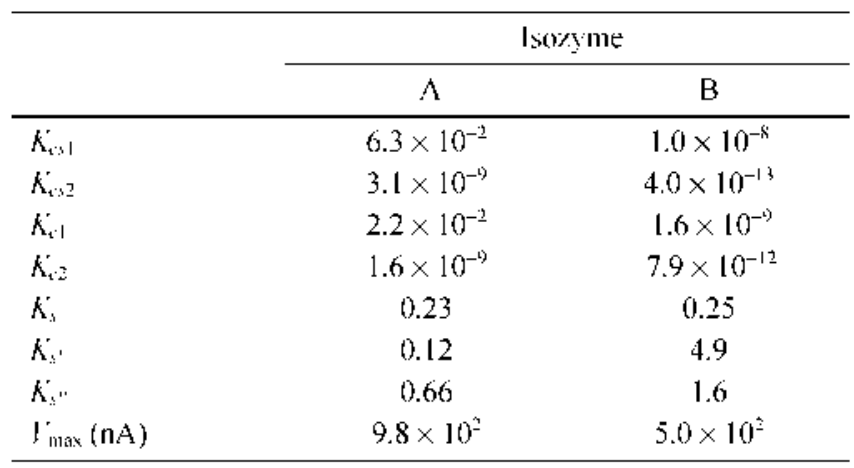

This is a straight line with a one-unit slope and an intercept at $\log \left(V_{\text {max }} K_{1}\right)+\log K_{: 1}$.

6) When $K_{(2} \gg\left[\mathrm{H}^{-}\right]$, logarithmic expression of the equation (3).

$$
\log \left(V / K_{m}\right)-\log \left(V_{\mathrm{mnR}} / K_{s}\right)-\log K_{\mathrm{t}^{\prime},}^{r}-\mathrm{pH}
$$

will be a straight line with slope of -1 and intercept of $\log \left(V_{\operatorname{mav}} / K_{s}\right)-\log K_{t 2}$ on the vertical axis. Equation (7). (8) and (9) were illustrated in figure 5 -(c) and (d). It shows that they intersect at a $\mathrm{pH}$ value equal to $\mathrm{pK}_{\mathrm{e} 1}$ and $\mathrm{pK}_{\mathrm{e} 2}$ for enzyme $A$ and $B$, respectively.

Using the relationships, $\frac{K_{i^{\prime}, 1}}{K_{c^{\prime} 1}}=\frac{K_{s^{\prime \prime}}}{K_{s}}$ and $\frac{K_{t^{\prime} x 2}}{K_{c^{\prime}, 2}}=\frac{K_{s}}{K_{s}}$. enables us to calculate $K_{r}$ and $K_{x}$. Table 4 lists all the thermodynamic parameters calculated.

When we designate $\mathrm{pH}$ dependent fractional composition as $F$, the general form of $F$ for the polyprotic acid $H_{n} A$ is

$$
\mathrm{F}_{\mathrm{H}_{f-\gamma / \mathrm{A}}}-\frac{K_{1} K_{2} \ldots K_{j}\left[\mathrm{H}^{+}\right]^{n /}}{D)}
$$

where $D-\left[\mathrm{H}^{\prime}\right]+K_{1}\left[\mathrm{H}^{\prime}\right]^{1,-1}+K_{1} K_{2}\left[\mathrm{H}^{\prime}\right]^{\prime \prime-2}-\cdots-K_{1} K_{2} K_{3}$ $\cdots K_{n}$.

Plots of $F$ versus $\mathrm{pH}$ show that the maxima values of $\mathrm{F}_{\mathrm{FII}}$

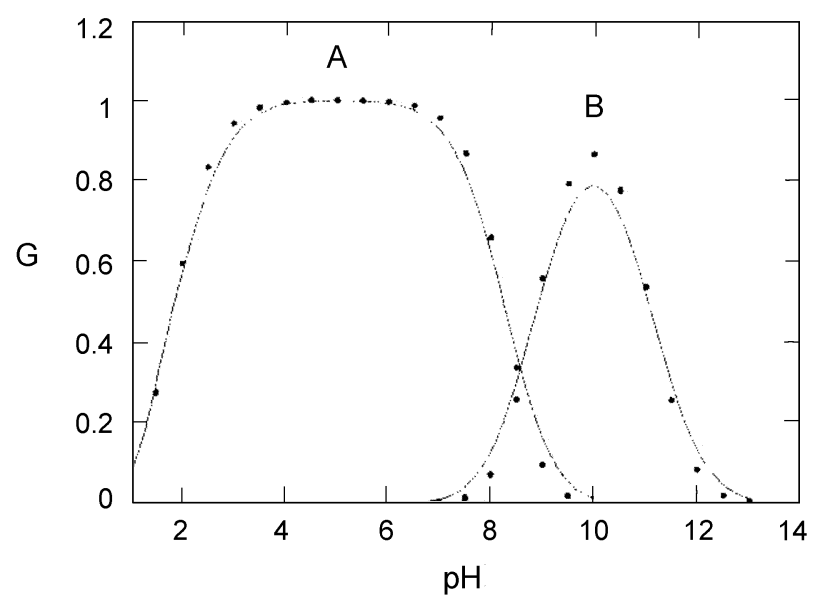

Figure 7. $\mathrm{p}^{\mathrm{H}}$-dependence of $\mathrm{C}\left(\mathrm{H}^{+}\right)$.
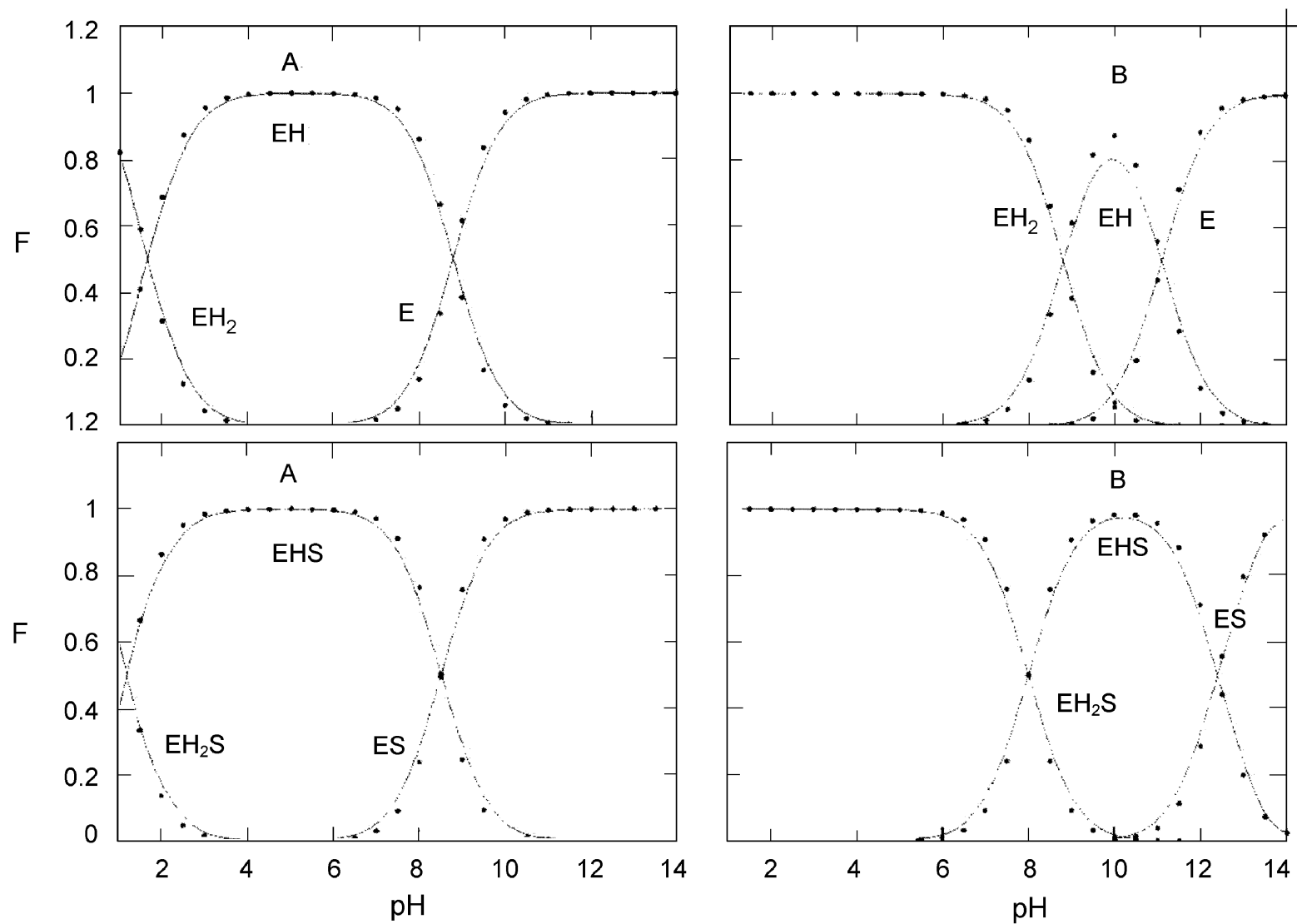

Figure 6. Fractional composition diagrams for peroxidase-proton and-substrate complexes. 
and $\mathrm{F}_{\mathrm{EHS}}$ are between $\mathrm{pH} 4$ and $\mathrm{pH} 6$ and between $\mathrm{pH} 9$ and $\mathrm{pH} \mathrm{ll}$ as shown in Figure 6. This coincides with the fact that Figure 3 already showed two peak currents around between $\mathrm{pH} 4$ and 8 , and between $\mathrm{pH} 8$ and $\mathrm{l}$. It is perhaps thought that the enzymatic catalysis is rather through the process. EH $+\mathrm{S} \rightarrow \mathrm{EHS} \rightarrow \mathrm{EH}+$ product. Presumably, it is informative and clear that the reaction rate is attributed to the joint contribution of $\mathrm{EH}$ and EHS. So a new functions connoting the characteristics of the joint contribution for isozyme $A$ and $\mathrm{B} . \mathrm{G}\left(\mathrm{H}^{+}\right)=\mathrm{F}_{\mathrm{EH}} \cdot \mathrm{F}_{\mathrm{EH}}$. can be defined. Figure 7 shows that maximum values of $\mathrm{G}\left(\mathrm{H}^{+}\right)$occur at around $\mathrm{pH} 5$ and at $\mathrm{pH} 10$. Conclusively it seems likely that these are optimum $\mathrm{pHs}$ of peroxidase isozymes extracted from horseradish.

\section{Conclusions}

The $\mathrm{pH}$-dependent current profile of the biosensor immobilizing the peroxidase extracted from horseradish showed two peaks and its electrophoretic expansion showed two major bands. Coincidence of the two events above enabled us to assume that the system consists of two isozymes and to resolve the current profiles into two Gausians. The application of the new Michaelis-Menten equation to the two Gausians made determine the optimum $\mathrm{pHs}$ of isozymes. It is believed that this electrochemical method will be helpful to deternine the optimum $\mathrm{pH}$ of other isozymes in many fields

\section{References}

1. Cortush-Bowden. A. Furdamentals of Enzme Kinetics. Butterworths: London. 1979: 130.

2. Dixon, M: Webb. E. C.: Thorne. C. J. R.: Tipton. K. F. Enzintes. 3rd ed.: Longmant: London1. 1979: p 138.

3. Laidler. K. J.: Bunting. P. S. The Chemical Kinetics of Enzyme? Action. 2nd ed.: Clarendon Press: Oxford, U. K., 1973; Ch. 5.

4. Tipton. K. F. Dixon, H. B. F. Methods Enzintol 1979. 63, 183.

5. Kirchner. J. R. Encyclopedia of Chentical Technolog: WileyInterscience: New York. U.S.A.. 1981: Vol. 13.p 12.

6. Irving Sax. N. Hawky's Condensed Chemical Dictionary: Van Nostrand Reinhold: New York. U. S. A.. 1987: p 618.

7. (a) Csöregi. E.; Jonsson-Pettersson. G.: Gorton. L. J. Biotechnol. 1993. 30. 315. (b) Oungpipat. W.: Alexander, P. W.: SouthwellKeely. P. Anal Chim. Acta 1995, 309, 35. (c) Rajendran, V: Csöregi. E.: Okanoto. Y.: Gortont. L. Anal. Chim. Acta 1998. 373 . 241. (d) Casero. E.: Darder. M.: Pariente. F.: Lorenzo. E. Anal. Chim. Acta 2002. 403. 1. (e) Miao. Y.: Tan. S. N. And. Chim. Acto 2001. $+37,87$

8. (a) Wijesuriva, D; Lin, M. S. Anal Chint Acta 1990, 234. 453 (b) Wang. J.: Naser. N.; Kwon. H. S.; Cho. M. Y. Anal Chint. Acta 1992. 264. 7. (c) Lin. M. S.: Tham. S. Y.: Rechnitz. G. A Electroanatysis 1990. 2. 511. (d) Fang. Y.: Cai. R.: Deng. J. Electroanalysis 1992. 4. 819. (e) Gaspar. S.: Habermuller. K.: Csöregi, E; Schumann, W. Sens, Achutors B 2001. 72, 63. (f) Li. B.: Zhang. Z; Jin, Y. Biosentors \& Bioelectronics 2002, 17 . 585.

9. Kwonl. H. S.: Kiml. K. K.: Lee. C. G. J. Koman Chem. Soc. 1996. 40(4). 278.

10. Yoon. K. J.: Pyun. S. Y.: Kwon. H. S. J. Korean Chem. Soc. 1997. H(7). 343 .

11. Yoon. K. J.: Kim. K. J.; Kwon. H. S. J. Korean Chem. Soc. 1999. $+3(3) .271$.

12. Yoon. K. J.: Lee. B. G.: Kwon. H. S. Anal. Sci. Tech 2000. 13(1). 41.

13. Lee. B. G.: Yoon. K. T.: Kwont. H. S. Anal. Sci. Tech 2000. 13(3). 315 .

14. Kwon. H. S.; Park, I. K.; Yoon. K. J.; Seo. M. L. J. Korew Chent. Soc. $2000,4+(4), 376$.

15. Lee. B. G.: Kwon. H. S.: Kim. K. E.: Yoon. K. I. Anal. Sci. Tech. 2001. $1+(3) .286$

16. The Philip Lief Group. Dictionary of Horficultwe: Viking Penguin: New York, U. S. A., 1994: p 133. 